\title{
Assessment of Level of Rural Infrastructure Development using Geospatial Techniques: A Case Study of Chandauli District (Uttar Pradesh), India
}

\author{
Dr. Sumana Sarkar* \\ Assistant Professor, Department of Geography, The University of Burdwan, Golapbag Academic Complex \\ Burdwan-713104, West Bengal, India
}

"Corresponding Author: Dr. Sumana Sarkar, Assistant Professor, Department of Geography, The University of Burdwan, Golapbag Academic Complex Burdwan-713104, West Bengal, India

\begin{abstract}
Advancement in geospatial techniques like remote sensing and GIS have facilitated the development and planning processes using spatial database approach. Database are generated following bottom to top hierarchy at different spatial scales i.e., micro level -village unit to meso level-state unit and up to macro level of country unit. Spatial database (SDA) with its unique characteristic of integrated map layouts with attributes tables has provided a better platform in framing the planning strategies with quick up gradation from time to time which facilitates to bring out both spatial as well as temporal variations in an easy and cost effective way. In present paper, an attempt has been made to generate SDA for assessing the existing spatial pattern of infrastructural development at inter-block level after selecting Chandauli district of Uttar Pradesh as a case study which is found helpful in rural infrastructure planning process.
\end{abstract}

Keywords: Geospatial Techniques, GIS, Spatial Database, Spatial Scales, Infrastructure.

\section{INTRODUCTION}

Infrastructure is an 'umbrella' term and it is referred to as social overhead capital by development economist Lewis (1955) ${ }^{[1]}$. It acts as a true 'engine of growth' in rural areas after playing a strategic role in producing large multiplier effects in its economy and is perhaps considered as the most vital ingredient for all kind of economic growth that rural India desires. Improvement in infrastructure facilities not only enhances the welfare but also speeded up economic growth in rural societies. In fact, it is a basic need to enhance marketability, efficient resource utilization and management after increasing opportunities for the local folk to participate in development process through which greater investment, employment and production can be generated in rural segments of an area. Hence, the heart of India beats for its rural based activities therefore, the assessment of spatial pattern of rural infrastructure, its development and planning are considered as an integral part of any developmental studies. A large number of researchers worked hard in this field some of them are cited here as Dadibhavi (1991) ${ }^{[2]}$, Ahmed (1992) $)^{[3]}$, Goyal (1998) ${ }^{[4]}$, Das (1998) ${ }^{[5]}$, Bhatia (1999) ${ }^{[6]}$, Joseph (1999) ${ }^{[7]}$, Durai (2000) ${ }^{[8]}$, Ghosh et al.(2004) ${ }^{[9]}$, Ansari (2005) ${ }^{[10]}$, Bhardwaj (2006) ${ }^{[11]}$ etc. In present study, an attempt has been made to generate SDB for the assessment of block level spatial disparities in the level of infrastructural facilities considering eight sectors viz. education, health, transport, communication, financial institution, electricity, irrigation, storage and veterinary services under the domain of Arc view 3.1 GIS software. Database is a collection of information about things and their relationship with each other ${ }^{[12]}$ and when the term spatial is added; it becomes very specific to a particular location on earth surface. The Spatial database (SDA) is an important feature of GIS which comprises both spatial or graphical layouts (point, line and polygon geometric units) along with its attribute information through a linkage mechanism for maintaining the topological characteristics to show the relationship between these two for the study of complexities of real world. SDB with its uniqueness of handling voluminous data in terms of data accumulation, storing, retrieval, gradation with suitable graphical map layouts and spatial analysis facilitates planning process easily. In GIS, there is need to capture geographical database once only then attributes information can be inserted and manipulated as and when required ${ }^{[13]}$. 


\section{STUdy AREA}

Chandauli district $\left(25^{\circ} 16^{\prime} \mathrm{N}\right.$ and $25^{\circ} 27^{\prime} \mathrm{N}$ latitude and $83^{\circ} 16^{\prime} \mathrm{E}$ and $83^{\circ} 27^{\prime} \mathrm{E}$ longitude) is situated at the lap of Ganga River in eastern most part of Uttar Pradesh sharing its boundary with Bihar in East and covers an area of $2541 \mathrm{~km}^{2}$ area with population of 1,639,777 persons (2001). It is bounded by the districts of Ghazipur in north and north-east, Sonbhadra in south, Mirzapur in south west and west and Varanasi in north-west. Physiographically the district comprises dual characters with an alluvial plain segment in north and portions of Vindhyan plateau in south.

It is basically rural in nature as more than 75 per cent share of its total population earns their livelihood from agriculture and allied activities. The district is well known for its excellent paddy production as 'Dhaan ka katora' of Uttar Pradesh. It comprises four Tahsils viz. Sakaldiha, Chandauli, Mughalsarai, and Chakiya with nine community development blocks (CDBs). These are Chahniya, Dhanapur, Sakaldiha, Niyamtabad, Chandauli, Barhani, Chakiya, Shahabganj and Naugarh blocks (Fig.1).
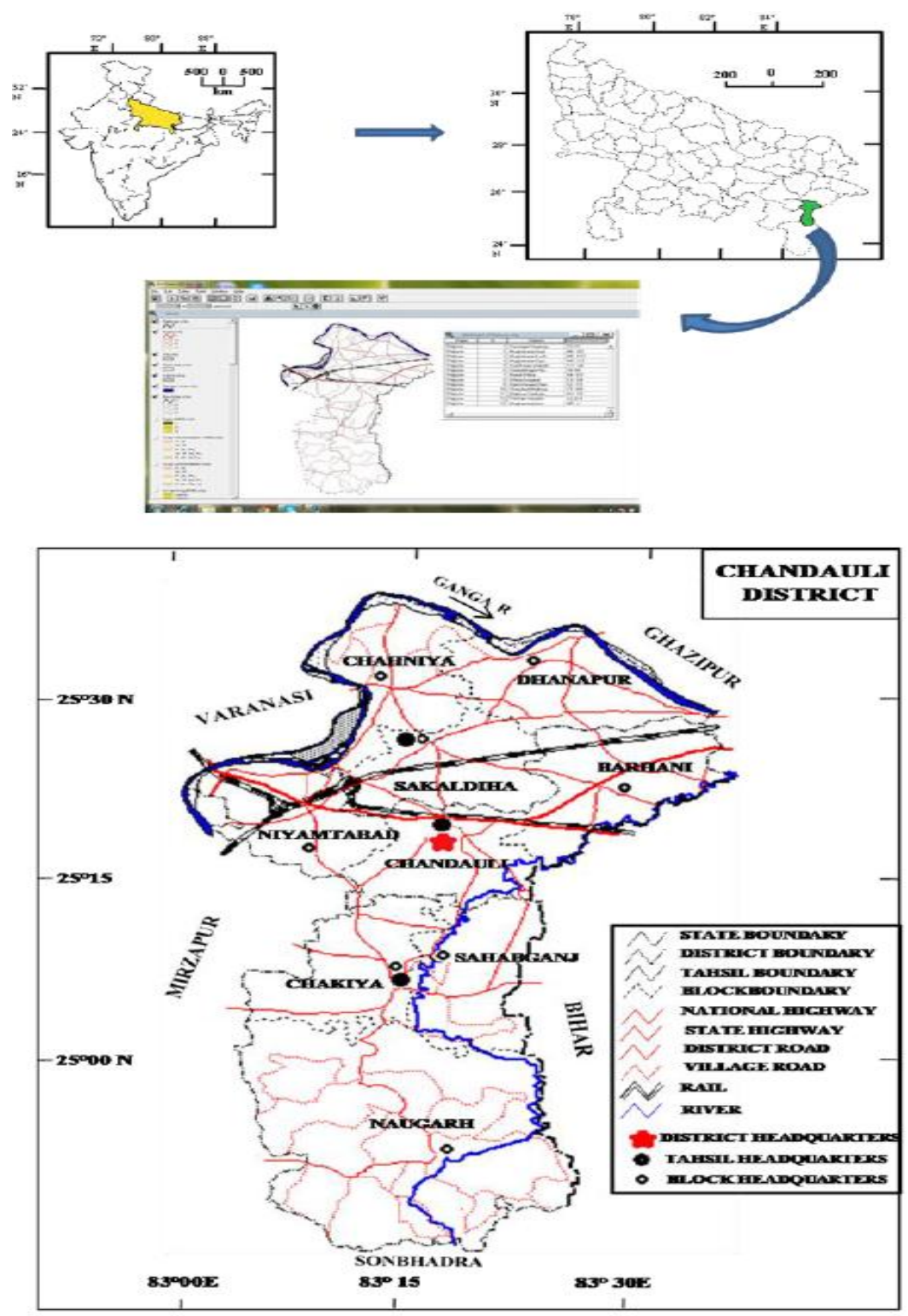

Fig1. Location of Study Area

(Source: Prepared by Author)

\section{OBJECTIVES Of STUdY}

- To assess the pattern of inter-block level spatial disparity of infrastructural development within the district adopting SDB approach. 
- To find out the root causes of regional disparity in terms of infrastructure development and to suggest some strategies for effective planning.

\section{DATA SETS AND Methodology}

The present study is purely based on secondary sources of data collected from the 2001, Census of India publications, New Delhi. SOI Toposheets (63 O and P), district planning map (NATMO) and IRS-1C, LISS-III satellite image (Row-103 and Path-54) are used to prepare a digital base map and other associated attribute information are obtained from district head quarter and statistical magazine for the year of 1999-2000 and 2009-2010. These collected information are then used as an input for generation of spatial database in Arc view 3.2 GIS software domain. To assess the level of infrastructural development, total forty five (45) variables are considered which comes under ten important sectors such as education, health, transport, communication, financial, electricity, storage, irrigation and veterinary services and are again broadly grouped in to three broad categories viz. social infrastructure, economic infrastructure and other infrastructure (Table 1). Next to this, thematic layer for each indicator has been generated manually with encoding numerical values for attribute information with the help of keyboard and analysis have been done by weighted score. Finally with vertical integration of different thematic layers one upon another and encoded with qualitative values such as good, moderate and low, a new thematic layer is generated for the analysis of spatial variations of level of infrastructure at block level. The most commonly used method for encoding spatial features are such as manual digitization with mouse and curser adopted for conversion of spatial unit into digital format (line or polygon)( see Fig. 2).

Table1. List of selected variables, Chandauli District (2000-10)

\begin{tabular}{|c|c|c|c|}
\hline \multirow{15}{*}{$\begin{array}{l}\text { Categories } \\
\text { social Infrastructure }\end{array}$} & Sub-categories & variables & Details \\
\hline & Education & $\mathrm{x}_{1}$ & No. of Psper lakh of population \\
\hline & & $x_{2}$ & No. of HPsper lakh of population \\
\hline & & $x_{3}$ & No. of Ssper lakh of population \\
\hline & & $x_{4}$ & $\%$ of inhabited villages having Ps \\
\hline & & $x_{3}$ & $\%$ of inhabited villages having HPs \\
\hline & & $x_{6}$ & $\%$ of inhabited villages havingss \\
\hline & Health & $x_{7}$ & No. of AH per lakh of population \\
\hline & & $x_{3}$ & No. of HH per lakh of population \\
\hline & & $x_{s}$ & No. of FMCWCS per lakh of population \\
\hline & & $\times_{10}$ & No. of bed per lakh of population \\
\hline & & $x_{11}$ & No. of doctorsper lakh of population \\
\hline & & $x_{12}$ & $\%$ of village s with $A H$ \\
\hline & & $\mathrm{x}_{1 \mathrm{~s}}$ & $\%$ of village s with $\mathrm{AH} / \mathrm{AYH} / \mathrm{UH}$ \\
\hline & & $\mathrm{x}_{14}$ & $\%$ of villages with FMCWCS \\
\hline \multirow{18}{*}{$\begin{array}{l}\text { Economic } \\
\text { Infrastructure }\end{array}$} & Transport & $x_{12}$ & Length of road (in $\mathrm{km}$.) per 1000 population \\
\hline & & $\mathrm{x}_{16}$ & Length of road (in km.) per $100 \mathrm{sq} . \mathrm{km}$. of area \\
\hline & & $x_{17}$ & $\%$ of inhabited villages connected with road \\
\hline & & $\mathrm{x}_{18}$ & No. of busstop per lakh populations \\
\hline & & $\mathrm{x}_{19}$ & $\%$ of villages with busstops \\
\hline & Communication & $x_{20}$ & Spatial concentration of $\mathrm{PO}$ \\
\hline & & $x_{21}$ & $\%$ of village s with PO \\
\hline & & $x_{22}$ & No. of tele-connection per lakh population \\
\hline & & $x_{2 s}$ & PCO booth per 100 sq. km. of area \\
\hline & Banking/Cre dit & $x_{24}$ & No. of PACCS per lakh population \\
\hline & & $x_{23}$ & No.PACCSper 100 sq. km. of area \\
\hline & & $x_{26}$ & Deposited capital per 1000Ag. Workers \\
\hline & & $x_{27}$ & Active capital per lakh Ag. Workers \\
\hline & & $x_{28}$ & Loan distributed per Ag. Worker \\
\hline & & $X_{2 s}$ & $\%$ of PACCS members to total Ag. Workers \\
\hline & & $x \geqslant 0$ & No. of banksper hundred sq. km. of area \\
\hline & & $x_{31}$ & No. of bank branch per lakh of rural population \\
\hline & & $x_{a 2}$ & No. of bank branchesper 10000 of Ag. workers \\
\hline \multirow[t]{13}{*}{ Othersinfrastructure } & Electricity & $x_{a g}$ & $\%$ of electrified villages \\
\hline & & $x_{s 4}$ & No. of electric pump per 100 ha of cultivated area \\
\hline & Storage & $x_{3}=$ & No. of seed and fertilizers storesper10o haNSA (net sown area) \\
\hline & & $x_{36}$ & Capacity of cold storage (in tones) per 100 hanSA \\
\hline & & $x_{a 7}$ & No. of seed and fertilizer sale centers per 100 haNSA \\
\hline & & $x_{B s}$ & No. of agricultural protection unit per 100 haNSA \\
\hline & & $x_{a g}$ & No. of agricultural service centresper 100 ha of NSA \\
\hline & Irrigation & $\times_{40}$ & Length of canal in $\mathrm{km}$. per 100 ha of NSA \\
\hline & & $x_{41}$ & No. of tube wellsper 100 ha of NSA \\
\hline & & $x_{42}$ & No. of pump setsper 100 ha of NSA \\
\hline & veterinary & $\mathrm{x}_{48}$ & No. of veterinary hospital per 10000 livestock \\
\hline & & $x_{\Delta 4}$ & No. of livestock development centre per 10000 livestock \\
\hline & & $x_{45}$ & No. of artificial bree ding centers and sub centersper 10000 livestock \\
\hline
\end{tabular}




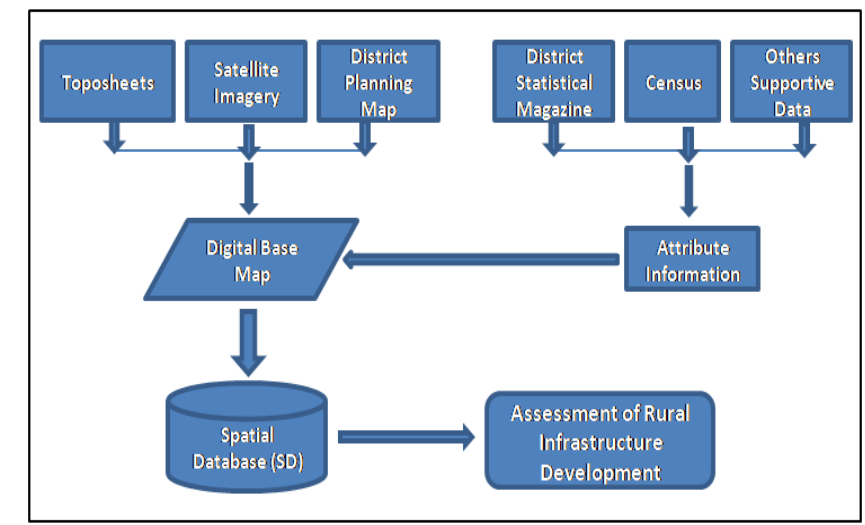

Fig2. Methodological Flow Chart

(Source: Prepared by Author)

\section{RESULTS AND DISCUSSION}

\subsection{Level of Social Infrastructure}

Education and health form the two pillars of social infrastructure by promoting mental and physical health of rural mass.

\subsubsection{Level of Educational Facilities}

Education is considered as the mirror to the society and is the seed as well as flower of socioeconomic development. It transforms human being from ignorance to enlightenment, from the shape of social backwardness to light of social amelioration and a nation from underdevelopment to faster social and economic development ${ }^{[14]}$. In the district, there are 1215 primary school (Ps), 554 higher primary school (HPs), 139 secondary school (Ss), 12 degree college and 6 PG colleges (Appendix 1). Among the total villages, almost 72 per cent villages have Ps within its territory. This number is declined for 26 per cent and 6 per cent for HPs and Ss respectively (Table 2). For the present study, six attributes are chosen such as, $X_{1}, X_{2}, X_{3}, X_{4}, X_{5}$ and $X_{6}$ (see Table 1) and map layouts are prepared for all themes. Then, after overlay analysis with weighted score method, level of education is determined for all the community development blocks (CDBs). There is huge gap in terms of spatial distribution of educational facilities. Higher index of education level is observed in two CDBs (Chahniya and Niyamtabad) located in northern and north western part of the district with an index value of 3.00 and above while lower index is in Chakiya and Chandauli i.e. below 2.00. Remaining blocks comes under moderate category (2.00-3.00). The study reveals that availability of educational facilities has a connection with nearness to existing urban centres such as Mughalsarai and Varanasi (Fig 3A and Table 3).

Appendix1. Number of Educational Institutions, Chandauli District (2000-2010)

\begin{tabular}{|l|l|l|l|}
\hline \multicolumn{1}{|c|}{ Institution } & \multicolumn{1}{c|}{$\mathbf{2 0 0 0}$} & \multicolumn{1}{c|}{$\mathbf{2 0 1 0}$} & \multicolumn{1}{c|}{ Variation (2000-2010) } \\
\hline Primary School (Ps) & 834 & 1215 & 45.68 \\
\hline Higher Primary School (HPs) & 241 & 554 & 129.88 \\
\hline Intermediate School (Ss) & 62 & 139 & 124.19 \\
\hline Degree College & 6 & 12 & 100 \\
\hline Master Degree College & 0 & 6 & - \\
\hline Poly-technique College & 1 & 1 & - \\
\hline
\end{tabular}

Source: District Statistical Magazine, Chandauli (2000-2010) and Personal Computation

Table2. Inhabited Villages and Distance of Educational Institutions in Chandauli District

\begin{tabular}{|l|l|l|l|l|l|l|}
\hline \multirow{2}{*}{ Distance (in km.) } & \multicolumn{2}{|c|}{ Primary School (Ps) } & \multicolumn{2}{c|}{ High Primary School (HPs) } & \multicolumn{2}{c|}{ Secondary School (Ss) } \\
\cline { 2 - 7 } & \multicolumn{1}{|c|}{ No. } & \multicolumn{1}{c|}{$(\boldsymbol{\%})$} & No. & \multicolumn{1}{c|}{ No. } & $(\boldsymbol{\%})$ \\
\hline Within Village & 1006 & 70.90 & 375 & 26.43 & 87 & 6.13 \\
\hline $0-1$ & 145 & 10.22 & 102 & 7.19 & 90 & 6.34 \\
\hline $1-3$ & 245 & 17.27 & 574 & 40.45 & 389 & 27.41 \\
\hline $3-5$ & 14 & 0.98 & 261 & 18.39 & 422 & 29.74 \\
\hline$>5$ & 9 & 0.63 & 107 & 7.54 & 431 & 30.38 \\
\hline Total & 1419 & 100 & 1419 & 100 & 1419 & 100 \\
\hline
\end{tabular}

Source: District Statistical Magazine, Chandauli (2009-2010) and Personal Computation 
Assessment of Level of Rural Infrastructure Development using Geospatial Techniques: A Case Study of Chandauli District (Uttar Pradesh), India

Table3. Block- wise Status of Educational Facilities in Chandauli District

\begin{tabular}{|l|c|c|l|}
\hline \multicolumn{1}{|c|}{ Status } & Range & No. of Blocks & \multicolumn{1}{c|}{ Community Development Blocks (CDBs) } \\
\hline High & Above 3.00 & 2 & Chahniya and Dhanapur \\
\hline Moderate & $2.00-3.00$ & 5 & Shahabganj, Naugarh, Niyamtabad, Sakaldiha and Barhani \\
\hline Low & Below 2.00 & 2 & Chandauli, Chakiya \\
\hline
\end{tabular}

Source: District Statistical Magazine, Chandauli (2009-2010) and Personal Computation

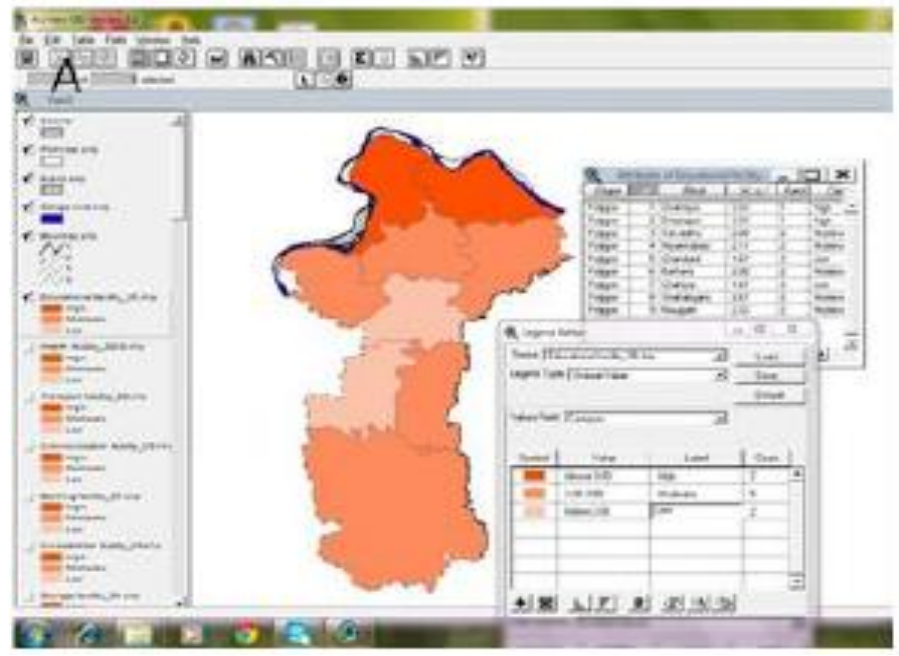

Fig3A. Level of educational facilities

\subsubsection{Level of Health Facilities}

Health is an essential input for the quality of life. Health and development interacts with each other. An improved health condition of the people helps to ensure the process of economic development in a positive way. Being a vital social infrastructure for any society it directly affects well beings of its people. A positive health status is defined as a state of complete physical, natural and social wellbeing and not merely the absence of diseases or infirmity ${ }^{[15]}$. It is observed that the availability of health facility is not satisfactory here in the district. There are insufficient number of health institutions such as 29 health units, 350 Family and Mother Child Welfare Centres (FMCWCS) and sub-centres to protect and promote the lives of rural people. The average distances of $57.79,20.51$, 14.58 and 7.12 percentage share of villages from allopathic dispensaries are about $5 \mathrm{~km}, 3-5,1-3$ and less than $1 \mathrm{~km}$ respectively. About 57.79 per cent villages are situated at a distance of more than $5 \mathrm{~km}$ away from Ayurvedic dispensaries. The percentage share of villages with in $3 \mathrm{~km}$ from mother child welfare centre is 56.59 (Table 4). To find out the level of health infrastructure, superimposition of selected layers of eight attributes $\left(\mathrm{X}_{7}, \mathrm{X}_{8}, \mathrm{X}_{9}, \mathrm{X}_{10}, \mathrm{X}_{11}, \mathrm{X}_{12}, \mathrm{X}_{13}\right.$ and $\left.\mathrm{X}_{14}\right)$ have been taken into consideration. Three blocks, viz. Sakaldiha, Shahabganj and Naugarh have comparatively better health infrastructure while six blocks such as Niyamtabad, Chandauli, Chakiya, Barhani, Chahniya and Dhanapur experienced poor condition due inadequate facilities in comparison to population (Fig.3B). The present analysis exposed that the low populated areas have a good composite values while the densely populated CDBs have low values. This is because of a persistent gap of available health institutions and population.

Table4. Distances of Inhabited Villages from Health Institutions in Chandauli District

\begin{tabular}{|l|l|l|l|l|l|l|l|l|l|l|}
\hline \multirow{2}{*}{$\begin{array}{c}\text { Distance } \\
\text { (in km.) }\end{array}$} & \multicolumn{2}{|c|}{ AH and PHC } & \multicolumn{2}{c|}{ AyH } & \multicolumn{2}{c|}{ OH } & \multicolumn{2}{c|}{ FWC/FWCs } & \multicolumn{2}{c|}{ MCWC/MCWCs } \\
\cline { 2 - 14 } & No. & \% & No. & \% & No. & \% & No. & \% & \multicolumn{1}{c|}{ No. } & \% \\
\hline Within village & 34 & 2.40 & 28 & 1.97 & 14 & 0.98 & 234 & 16.49 & 224 & 15.78 \\
\hline $0-1$ & 67 & 4.72 & 49 & 3.45 & 17 & 1.20 & 65 & 4.58 & 76 & 5.35 \\
\hline $1-3$ & 207 & 14.59 & 197 & 13.88 & 82 & 5.78 & 504 & 35.52 & 558 & 39.32 \\
\hline $3-5$ & 291 & 20.51 & 325 & 22.90 & 172 & 12.12 & 352 & 24.80 & 335 & 23.61 \\
\hline$>5$ & 820 & 57.79 & 820 & 57.70 & 1134 & 79.91 & 264 & 18.60 & 206 & 14.52 \\
\hline
\end{tabular}

Source: District Statistical Magazine, Chandauli (2009-2010) and Personal Computation

Note: AH -Allopathic hospital, PHC-public health centre, AyH-Ayurvedic hospital, OH-Other hospital, 
FWC/FWCs- Family welfare centres and sub-centres, MCWC/MCWCs-Mother child welfare centre and sub centres.

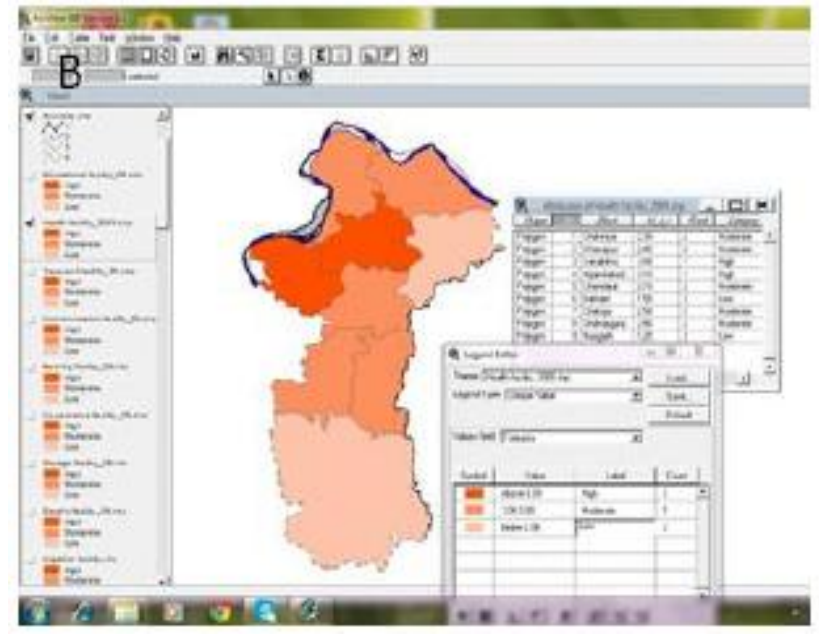

Fig3B. Level of health facilities

\subsection{Level of Economic Infrastructure}

Transport, communication and financial institutions form base of economic infrastructure and are directly linked with the economic progress of a region. Both transport and communication facilities are complimentary to each other and the progress in one accelerates the development in other. Together they promote economic development and reduce socio-economic disparities at either intra or inter-regional level.

\subsubsection{Level of Transport Facilities}

Rural transport network system acts as an engine of rural development. Development of rural transport assumes special importance from the point of view of economic integration of the rural areas with the administration, marketing and servicing centres. These linkages bring different areas in close contact after promoting interaction between villages and with towns ${ }^{[16]}$.

There are $191 \mathrm{~km}$. long broad gauge main line of Eastern and Northern Railway with 14 halts distributed in four CDBs (Sakaldiha-4, Niyamtabad-2, Chandauli-2 and Barhani -4) and a large junction of Mughalsarai. Among the available road length $(2393 \mathrm{~km}$.), $1958 \mathrm{~km}$., $355 \mathrm{~km}$. and $80 \mathrm{~km}$. are maintained by Public works Department, Forest department and local bodies respectively. According to the functional importance of roads, the study area is covered by $59 \mathrm{~km}$. of National highway (NH-2), $101 \mathrm{~km}$. of State highway with a large share of $1774 \mathrm{~km}$. of other district and rural roads.

A composite layer is generated on the basis of agglomeration of five selected variables $\left(\mathrm{X}_{15}, \mathrm{X}_{16}, \mathrm{X}_{17}\right.$, $\mathrm{X}_{18}$ and $\mathrm{X}_{19}$ ) related transport sectors. The study depicts that there is a wide spatial variation of transport facilities development in the district. Physiographic factors play a crucial for the construction and availability of transport lines (Fig.3C and Table 5).

Table5. Block-wise Status of Road Facilities in Chandauli District

\begin{tabular}{|l|c|c|c|}
\hline \multirow{2}{*}{$\begin{array}{l}\text { Community Development } \\
\text { Block (CDB) }\end{array}$} & \multicolumn{2}{|c|}{ Length of Road } & \multirow{2}{*}{$\begin{array}{c}\text { \% of villages } \\
\text { connected with metal road }\end{array}$} \\
\cline { 2 - 4 } & $\mathbf{k m / L a k h ~ P o p u l a t i o n}$ & $\mathbf{k m ~ / 1 0 0 ~ s q . k m}$ & 70 \\
\hline Chahniya & 1.44 & 111 & 100 \\
\hline Dhanapur & 1.21 & 99 & 80 \\
\hline Sakaldiha & 1.03 & 102 & 81 \\
\hline Niyamtabad & 1.14 & 154 & 62 \\
\hline Chandauli & 1.50 & 135 & 67 \\
\hline Barhani & 1.45 & 82 & 53 \\
\hline Chakiya & 1.65 & 115 & 81 \\
\hline Shahabganj & 1.75 & 83 & 64 \\
\hline Naugarh & 3.13 & 100 & \\
\hline
\end{tabular}

Source: District Statistical Magazine, Chandauli (2009-2010) and Personal Computation 


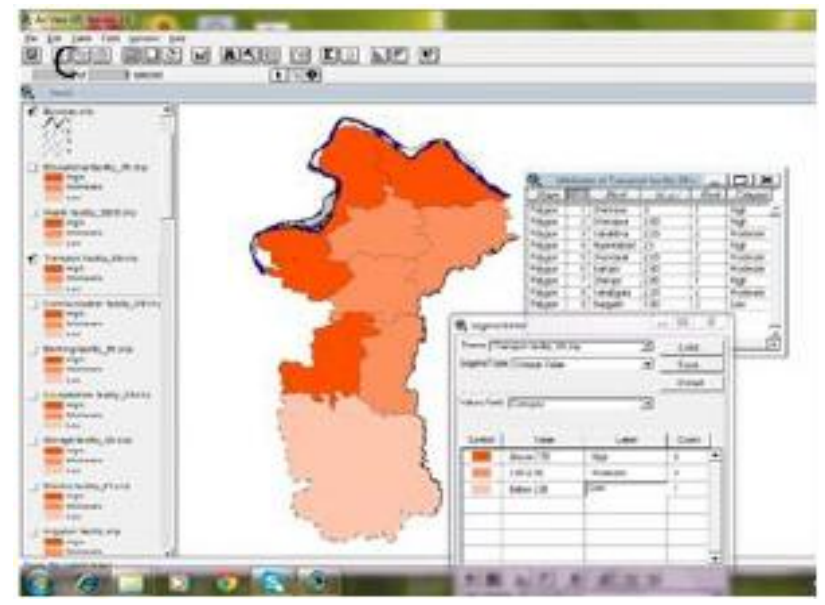

Fig3C. Level of transport facilities

\subsubsection{Level of Communication Facilities}

The availability of adequate, efficient and cost effective communication facilities not only promote socio-economic development of a region but also accelerate its growth and development. In Chandauli district, two modes of communication services are available viz. Postal and Telephoneconnectivity. Besides these radio, television and group information network also play a crucial role to strengthen the communication development level of rural community. In the present study, four variables $\left(\mathrm{X}_{20}, \mathrm{X}_{21}, \mathrm{X}_{22}\right.$ and $\left.\mathrm{X}_{23}\right)$ are chosen based on availability of data regarding number of post offices (PO) and tele- connectivity. There are 178 post offices in the district. The spatial concentration of $\mathrm{PO}$ is not uniform throughout the district and it varies from higher concentration (Above $15 \mathrm{PO}$ per lakh population) in Chahniya and Shahabganj to lower concentration (below 5 per lakh people) in Niyamtabad. Remaining five CDBs are confined to moderate category zone. About 69 per cent of villages have $\mathrm{PO}$ within $3 \mathrm{~km}$. of its territory.

Telecommunication network is crucial and essential ingredient for betterment of rural connectivity and considered as a symbol of modernity. According to Alvin Toffler, it has shrunk local and international boundaries expanded the flow of people, commodities, money and information beyond the confines of individual systems and states. The higher number of telephone connection per lack population is observed here in three CDBs viz. Chahniya, Dhanapur and Chakiya. The density of Public call offices (PCOs) varies from highest Niyamtabad (88 per $100 \mathrm{sq} . \mathrm{km}$.) to lowest one in Naugarh (8 per 100 sq. km.). Remaining six CDBs (Dhanapur, Chahniya, Sakaldiha, Chakiya, Chandauli and Shahabganj) fall into medium category. According to the distance between inhabited villages and available PCO sites, there are 71.45 per cent of villages having PCO with in $3 \mathrm{~km}$. distance (Appendix 2). The higher percentage share of villages having PCO within its territory is found in Dhanapur and Chahniya while the lowest index value occurs in Chakiya. Remaining blocks consist of moderately high (50-70 per cent) and moderately low (30-50 per cent) comprising each of 3 blocks respectively (Fig. 3D and Table 6).

Appendix2. Distance wise Number of Inhabited Villages Availing Transport \& Communication Facilities, Chandauli District

\begin{tabular}{|c|l|l|l|l|l|l|l|l|l|l|}
\hline \multirow{2}{*}{$\begin{array}{c}\text { Distance } \\
\text { (in km.) }\end{array}$} & \multicolumn{2}{|c|}{ Pucca Road } & \multicolumn{2}{|c|}{ Post office } & \multicolumn{2}{c|}{ Letter box } & \multicolumn{2}{|c|}{ PCO } & \multicolumn{2}{c|}{ Bus stop } \\
\cline { 2 - 12 } & $\begin{array}{c}\text { No. of } \\
\text { Villages }\end{array}$ & $\mathbf{\%}$ & $\begin{array}{c}\text { No. of } \\
\text { Villages }\end{array}$ & $\mathbf{\%}$ & $\begin{array}{c}\text { No. of } \\
\text { Villages }\end{array}$ & $\mathbf{\%}$ & $\begin{array}{c}\text { No. of } \\
\text { Villages }\end{array}$ & $\%$ & $\begin{array}{c}\text { No. of } \\
\text { Villages }\end{array}$ & $\%$ \\
\hline Within village & 1011 & 71.25 & 161 & 11.35 & 341 & 24.03 & 732 & 51.58 & 175 & 12.33 \\
\hline $0-1$ & 91 & 6.41 & 110 & 7.75 & 102 & 7.19 & 51 & 3.59 & 94 & 6.62 \\
\hline $1-3$ & 260 & 18.32 & 623 & 43.90 & 600 & 42.28 & 231 & 16.28 & 389 & 27.41 \\
\hline $3-5$ & 36 & 2.54 & 269 & 18.96 & 232 & 16.35 & 172 & 12.12 & 259 & 18.25 \\
\hline$>5$ & 21 & 1.48 & 256 & 18.04 & 144 & 16.15 & 233 & 16.42 & 502 & 35.38 \\
\hline Total & 1419 & 100 & 1419 & 100 & 1419 & 100 & 1419 & 100 & 1419 & 100 \\
\hline
\end{tabular}

Source: District Statistical Magazine, Chandauli (2009-2010) and Personal Computation 


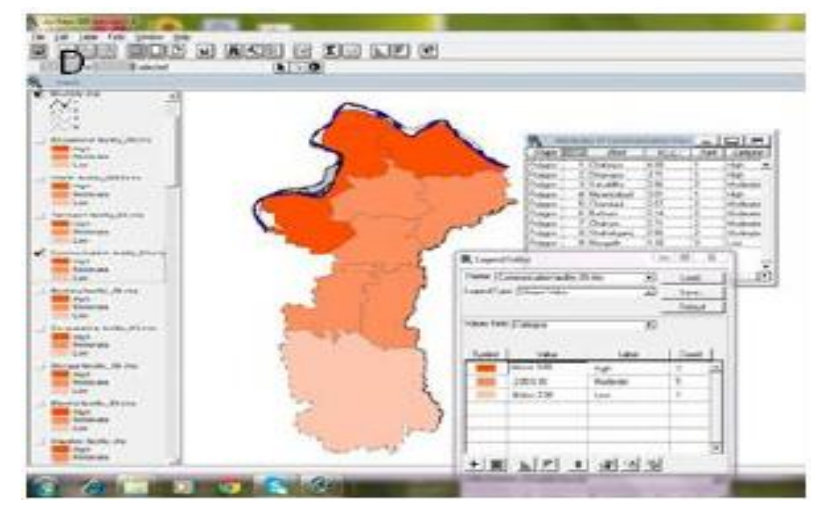

Fig3D. Level of communication facilities

Table6. Spatial distribution of communication facilities in Chandauli district

\begin{tabular}{|l|l|l|l|l|}
\hline \multicolumn{1}{|c|}{ Category } & \multicolumn{1}{|c|}{ PO } & \multicolumn{2}{c|}{ Personal Tele phone Connection } \\
\cline { 2 - 5 } & No./lakh population & \multicolumn{1}{c|}{ Blocks } & No./lakh population & \multicolumn{1}{c|}{ CDBs } \\
\hline High & Above 15 & Chahniya and Shahabganj & Above 250 & $\begin{array}{l}\text { Chahniya, } \\
\text { Dhanapur, Chakiya }\end{array}$ \\
\hline $\begin{array}{l}\text { Moderately } \\
\text { high }\end{array}$ & $10-15$ & $\begin{array}{l}\text { Dhanapur, Barhani, Chakiya, } \\
\text { Sakaldiha, Chandauli }\end{array}$ & $200-250$ & $\begin{array}{l}\text { Niyamtabad, } \\
\text { Shahabganj }\end{array}$ \\
\hline $\begin{array}{l}\text { Moderately } \\
\text { low }\end{array}$ & $5-10$ & Naugarh & $150-200$ & $\begin{array}{l}\text { Chandauli } \\
\text { Sakaldiha }\end{array}$ \\
\hline Low & Below 5 & Niyamtabad & Below 150 & Barhani, Naugarh \\
\hline
\end{tabular}

Source: District Statistical Magazine, Chandauli (2009-2010) and Personal Computation

\subsubsection{Level of Financial Facilities}

Financial institutions provide credit to rural people as per their norms and deposit their savings. Credit is an important input in the development process; it acts as an accelerator of development ${ }^{[17]}$. Rural credit performs through a multiagency system comprising cooperatives, commercial banks and regional rural banks. There are national banks (45), rural banks (30) and non-commercial banks (14) in the district. Union bank of India leads here with its 17 branches followed by SBI (14), Bank of Baroda (7). Other than these, Land development bank, District cooperative bank and Kashi Gomti Samyat Gramin Bank have 2, 10 and 30 branches respectively.

In order to measure the level of financial infrastructure development, nine indices have been selected such as $X_{24}, X_{25}, X_{26}, X_{27}, X_{28}, X_{29}, X_{30}, X_{31}$ and $X_{32}$ (see Table 1). Study reveals that Chakiya, Chandauli, Niyamtabad, Barhani, Shahabganj, Chahniya and Dhanapur have comparatively better cooperative facility whereas the remaining 2 blocks are not in good position. It is also observed that comparatively better banking facility is confined in the eight CDBs (Chahniya, Dhanapur, Sakaldiha, Niyamtabad, Shahabganj, Naugarh and Chandauli) while others encountered with deprived situations. A composite layout of economic infrastructure shows that Chahniya and Niyamtabad perform well in comparison to poor performer blocks such as Sakaldiha, Barhani and Naugarh due to their strategic position (Fig. 3E and F).

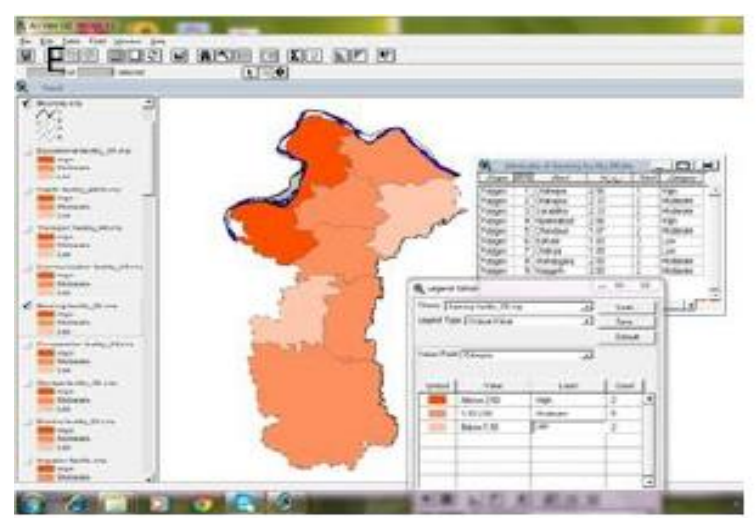

Fig3E. Level of banking facilities

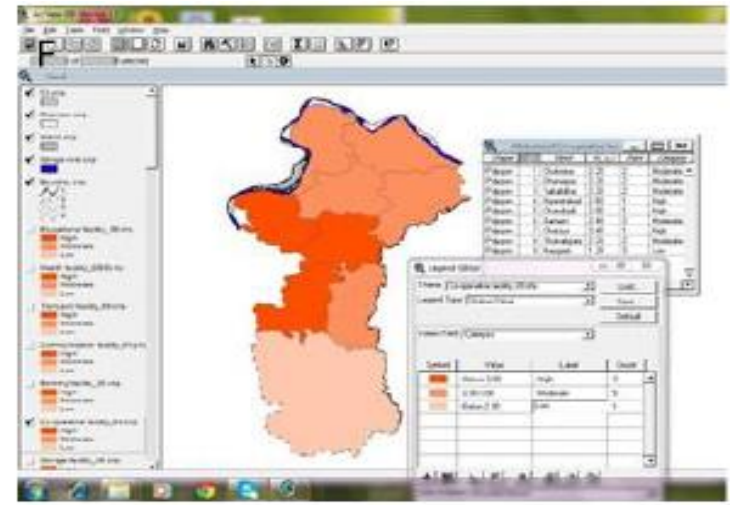

Fig3F. Level of infrastructure facilities 


\subsection{Level of Other Infrastructure}

In present study, four facilities such as electricity, storage, irrigation and veterinary service are considered under other infrastructure. Development of each of the above mentioned facilities either directly or indirectly promote development in others.

\subsubsection{Level of Electric Facilities}

Electricity plays as a catalyst in triggering off rural development, further an adequate power infrastructure is a necessary requirement for rural industrialization and rural social services apart from agriculture. It became a symbol of development and modernization specially in agricultural sector by maximizing the use of underground water for irrigation. Besides these, it further provides amenities of modern living such as house and street lighting, fans electrification and also introduces a sense of urbanism into rural life ${ }^{11}$. In 1998-99, only 83.45 per cent villages were electrified and in 2008-09 it increase up to 91.26 per cent. In 1999 there were only 8289 private electric pump sets which increase to 13,594, i.e., 64 percent growth in 2009. Four blocks (Dhanapur, Chahniya, Niyamtabad and Chakiya) out of total 9, have high electrified villages (above 95 per cent electrified villages) (see Table 7). Only Naugarh have lower percentage share of electric connection to villages (i.e. below 75 electrified villages). Again number of electric hand pump-set is high in blocks of northern alluvial belt and low in southern plateau tract. The level electric facility is high in Chahniya Niyamtabad, Dhanapur, Chakiya followed by 4 blocks of moderate condition along with the poor condition in Naugarh (Fig. 3G).

Table7. Spatial Pattern of Electric Facilities in Chandauli district

\begin{tabular}{|l|l|l|l|l|}
\hline \multicolumn{1}{|c|}{ Category } & $\begin{array}{c}\text { \% of electrified } \\
\text { villages }\end{array}$ & Name of CDBs & $\begin{array}{c}\text { No. of electric pump } \\
\text { sets/100ha. NSA }\end{array}$ & \multicolumn{1}{|c|}{ Name of CDBs } \\
\hline High & Above 95 & $\begin{array}{l}\text { Dhanapur, Chahniya } \\
\text { Niyamtabad, Chakiya }\end{array}$ & Above 15 & Chahniya \\
\hline Moderately high & $85-95$ & Sakaldiha, Chandauli & $10-15$ & $\begin{array}{l}\text { Dhanapur, Niyamtabad, } \\
\text { Shahabganj, Chakiya }\end{array}$ \\
\hline Moderately low & $75-85$ & Barhani, Shahabganj & $5-15$ & Chandauli, Sakaldiha, Barhani \\
\hline Low & Below 75 & Naugarh & Below 5 & Naugarh \\
\hline
\end{tabular}

Source: District Statistical Magazine, Chandauli (2009-2010) and Personal Computation

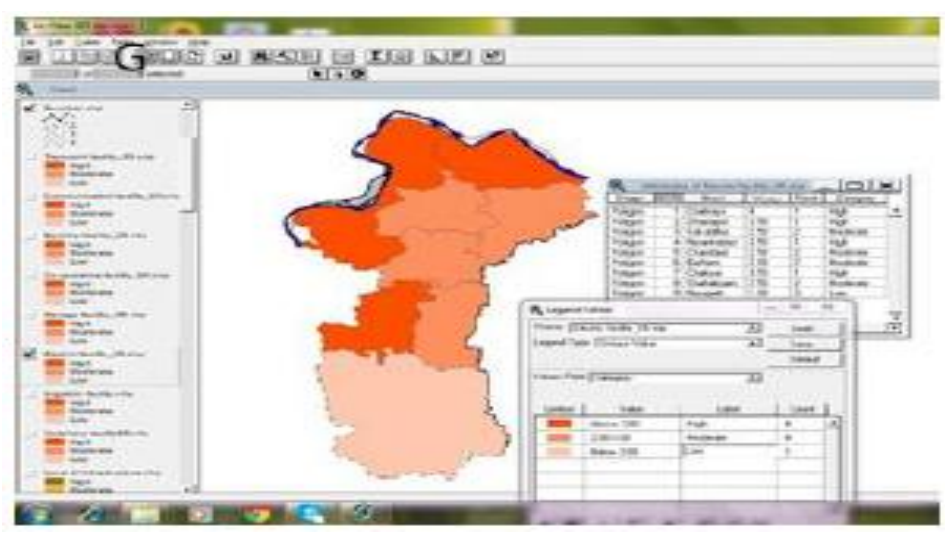

Fig3G. Level of electric facilities

\subsubsection{Level of Storage Facilities}

Proper storage of surplus agricultural product determines the economic profit of rural farmers. In Chandauli district, there are seed godown (88) and fertilizer storage centres (86) with capacity of 9300 tones. Block wise distribution shows that Chandauli and Barhani have 28 godown each followed by Sakaldiha Dhanapur and Chahniya and the lowest is found in Naugarh. There are also 143 seed sale centres and 325 fertilizer sale centres distributed unevenly and 9 agricultural protection units situated one in each block. Other than these, there are 32 agricultural service centres and 2 cold storages with a capacity of 6577 tone in Niyamtabad.

To chalk out the overall condition of storage facility, five indicators have been considered $\left(\mathrm{X}_{35}, \mathrm{X}_{36}\right.$, $\mathrm{X}_{37,} \mathrm{X}_{38}$ and $\mathrm{X}_{39}$ ). Then, after calculating weighed composite values for each of the blocks, map layout is generated adopting SDB approach for the present analysis. 
The study depicts that storage facility has a positive connection with better supply of electricity. It is observed that the blocks having comparatively better storage are Chahniya and Niyamtabad while Naugarh and Barhani registered poor storage facilities (Fig. 3H).

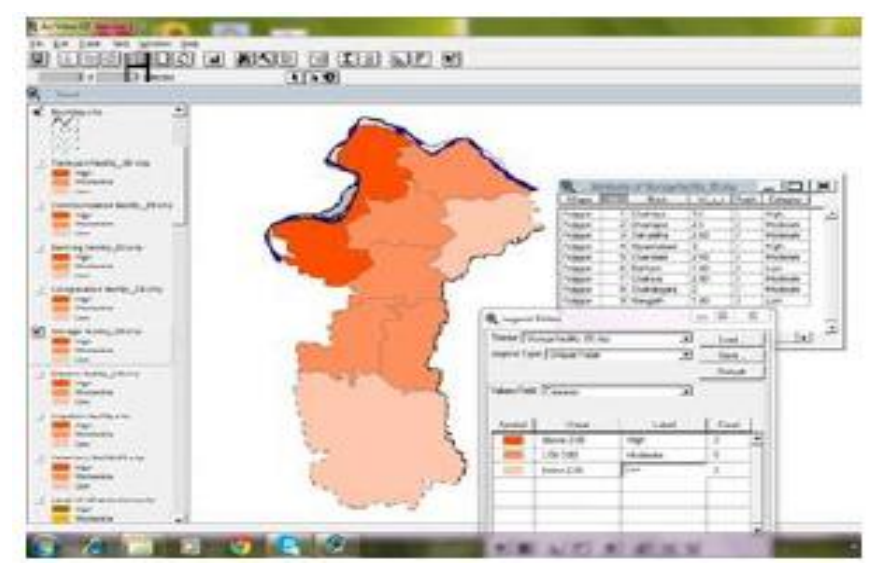

Fig3H. Level of storage facilities

\subsubsection{Level of Irrigation Facilities}

Irrigation plays a key role in rural development by supporting agriculture with waters as modern agricultural practices need insurance of adequate amount of water to the field to grow crops all the year round ${ }^{[18]}$. Canal is the main source of irrigation with an area coverage of 1, 10,409 ha followed by tube wells (15,316 ha) and other sources (3554 ha) in Chandauli. During 1998-99 to 2008-09, there was a remarkable growth of private tube wells which imply small and marginal farmers but explicated the precious ground waters (see Appendix 3).

Appendix3. Mode of Irrigation and It's Temporal Variations, Chandauli District

\begin{tabular}{|c|c|c|c|}
\hline Item & 2000 & 2010 & Variation (\%) \\
\hline Canal length (in km.) & 514 & 534 & 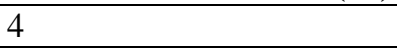 \\
\hline Govt. tube-well (no.) & 237 & 246 & 3.80 \\
\hline Private tube-well (no.) & 815 & 14,459 & 1674 \\
\hline Permanent well (no.) & 0 & 431 & - \\
\hline Rahat & 0 & 286 & - \\
\hline
\end{tabular}

Source: District Statistical Magazine, Chandauli (2000-2010) and Personal Computation

In order to assess the level of irrigation facilities following three parameters have been selected such as $\mathrm{X}_{40}, \mathrm{X}_{41}$ and $\mathrm{X}_{42}$. Comparatively higher index values (above 2.50) of irrigational facilities have been observed in Dhanapur, Chakiya Chandauli, Chahniya, Sakaldiha, Shahabganj whereas remaining blocks come under moderate (1.50-2.50) and low (below 1.50) categories respectively (Fig. 3I).

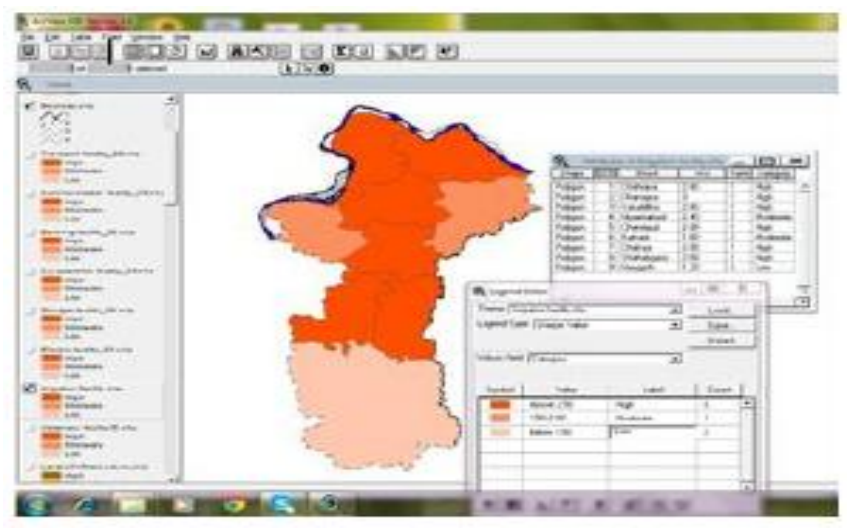

Fig3I. Level of irrigation facilities

\subsubsection{Level of Veterinary Facilities}

Livestock sectors play a significant role in supplementing family incomes and generating gainful employment for rural mass. Therefore, proper development of this infrastructure will enhance the 
livestock resource generating capacity and further boosting rural economy. There are 16 veterinary hospitals (VH), 21 livestock development centres (LDC) and 29 artificial breeding centres. Beside that there are 11 sheep development centre distributed evenly except Sakaldiha, Niyamtabad and Barhani block and 3 piggery development units in Dhanapur, Barhani and Chakiya.

Three indicators have been selected to assess the level of veterinary facilities $\left(\mathrm{X}_{43}, \mathrm{X}_{45}\right.$ and $\left.\mathrm{X}_{46}\right)$. The categories have been decided for each thematic layer with ranking values and finally composite index is calculated to get the picture of overall level of development of veterinary facilities. Study reveals that two blocks viz. Chakiya and Shahabganj are positioned in high category, four blocks in medium category followed by three in poor category (Fig. 3J).

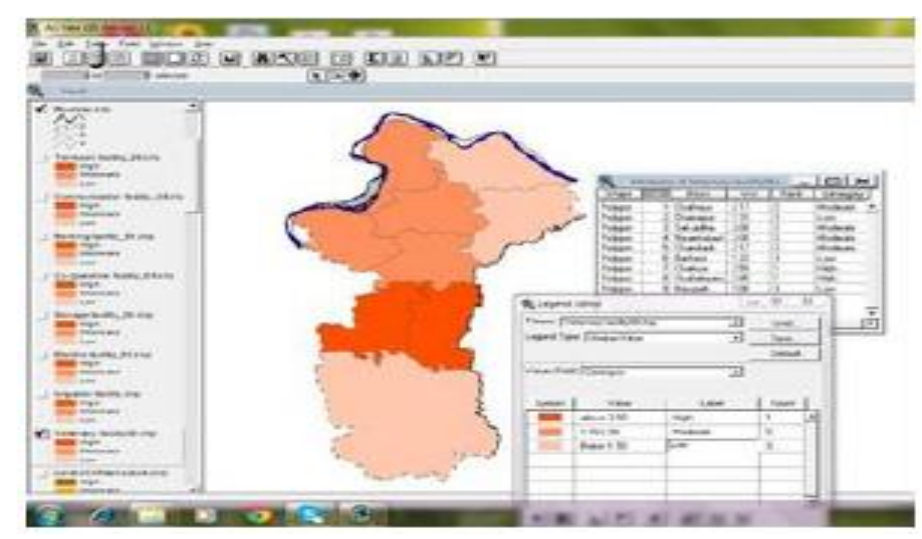

Fig3J. Level of infrastructure facilities

\subsection{Level of Development of Integrated Infrastructure Facilities and Planning}

Analysis of each sector of infrastructure facilities reveals that their spatial distribution is not uniform in the whole district. One observation has been drawn that there is a contrast pattern of distribution of number of facilities with per lakh of population and per $100 \mathrm{sq} . \mathrm{km}$. of area. In plain areas as the population is high the number of available facilities are low but their density is high in such areas while in plateau region as the number of population is comparatively less the available number of infrastructure facilities is high but the density is low. The resultant outcome showing variations in analysis of these two types of data, therefore, suitable conclusion may hardly be drawn. Keeping these facts in mind, an attempt has been made to assess the relative position of CDBs in terms of their level of infrastructure development after taking into account both types of data analysis under different sectors such as (Xa) Education facilities, $(\mathrm{Xb})$ Health facilities, (Xc) Transport facilities, (Xd) Communication facilities, (Xe) Banking facilities, (Xf) Cooperative Institution facilities, (Xg) Storage facilities, (Xh) Electric facilities, (Xi) Irrigational facilities and (Xj) Veterinary facilities (Fig. $4 \mathrm{~A}$ ).

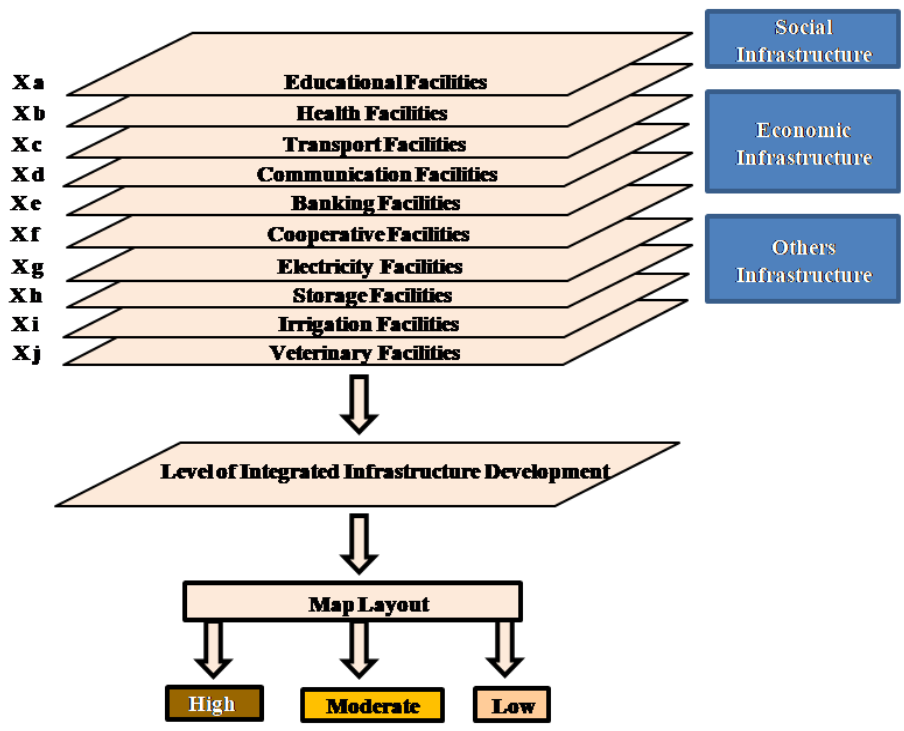

Fig4A. Level of integrated infrastructure Development in Chandauli District, 2009-10

(Source: Prepared by Author) 
Ten thematic layers were accounted as input files and the final output for the level of infrastructure development is generated after applying integrated overlay technique under GIS environment. On the basis of mean and standard deviation, the categories were decided under all the above mentioned ten thematic layers and ranking had been done for high, moderate and low as 1,2 and 3 respectively. Then with these composite index values for each facilities in each CDBs, database for the integrated level of development is generated. The blocks are grouped into three categories viz. High, Moderate and Low. Three blocks viz. Chahniya, Niyamtabad and Dhanapur are enjoying high level of infrastructure development. Only two blocks fall in to low level of development (Naugarh and Barhani) and remaining blocks are experiencing moderate level (Fig. 4B and Table 8).

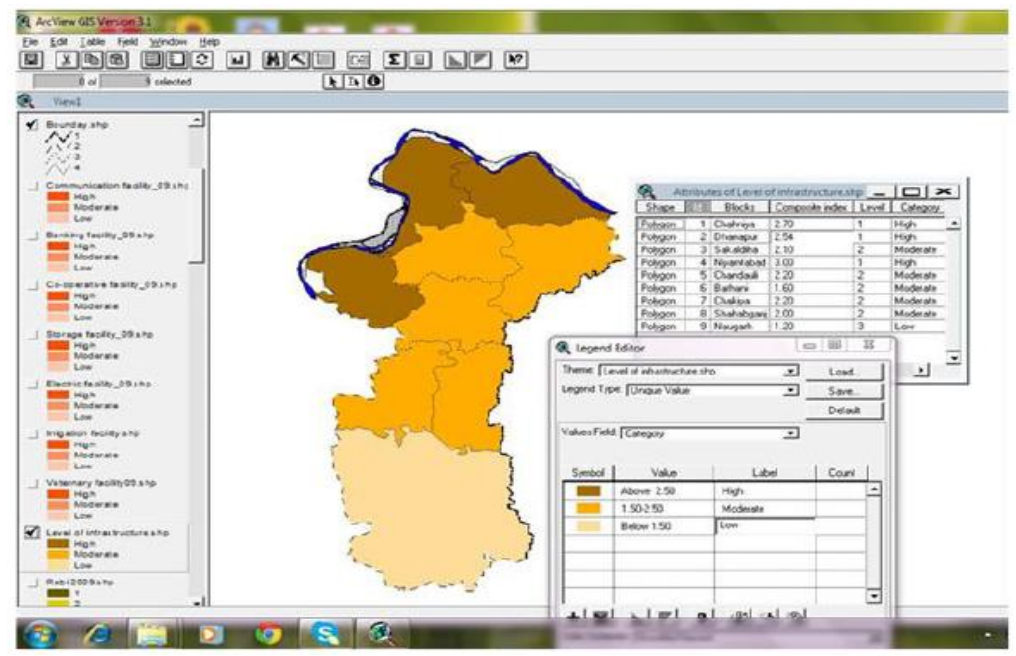

Fig4B. Level of integrated infrastructure Development in Chandauli District, 2009-10

Table8. Status of Integrated Infrastructural Development, Chandauli District

\begin{tabular}{|l|l|l|l|}
\hline Category & \multicolumn{1}{|c|}{ Range } & \multicolumn{1}{c|}{ No. of CDBs } & \multicolumn{1}{c|}{ Name of CDBs } \\
\hline High & Above 2.50 & 3 & Chahniya, Niyamtabad, Dhanapur \\
\hline Moderate & $2.00-2.50$ & 4 & Chandauli, Chakiya, Shahabganj, Sakaldiha, \\
\hline Low & Below 2.00 & 2 & Barhani, Naugarh \\
\hline
\end{tabular}

Source: District Statistical Magazine, Chandauli (2009-2010) and Personal Computation

Blocks in northern plain areas occupy relatively better position because of nearness to Varanasi, Ramnagar industrial area and Mughalsarai urban centres. This strategic location generates multiplier effects of different facilities while blocks located in southern portion comprising part of Vindhyan plateau and associated fringe areas, have encountered with problems of physical inaccessibility which acts as a main barrier for against proper infrastructure development. Among these blocks Naugarh acts as a buffer zone for intra-district and inter- state Naxalise activities.

\section{CONCLUSION}

The findings of the study portray a general perception about overall condition of level of infrastructure development in Chandauli district. The blocks in the district are marked with wide range of disparity in overall development. It has been observed that different sector of infrastructure links with one another and development of one has speeded another one.

On the basis of status of development, the CDBs are categorised under three priority zones. Blocks having low, medium and high level of infrastructure development are placed in to first, second and third priority zones respectively for planning purpose.

It may also be concluded that GIS with its unique features of SDB can be used effectively as a capacity building tool and technique by researchers, planners, local government and other stake holders to formulate planning strategies for the overall development of rural area in general and its infrastructure in particular.

\section{REFERENCES}

[1] Allen Lewis W., Theory of Economic Growth, George Allen \& Unwin Ltd. London (1955). 
[2] Dadibhavi R.V., Disparities in Social Infrastructural Development: 1970-71 to 1983-84, Asian Economic Review.33 (1) (1991).

[3] Ahmed, R. and Donovan, C., Issues of Infrastructural Development: A synthesis of the Literature, Washington DC, International Food Policy Research Institute (1992).

[4] Goyal L.C., An Introspection on Some Aspects of Infrastructure, Yojana.42, 21(1998).

[5] Das P.M., Role of Transport sector in Accelerating Development, Yojana. 42 (8), (1998).

[6] Bhatia M.S., Rural Infrastructure and Growth in Agriculture, Economic and political weekly. 27 (3), A45 (1999).

[7] Joseph A., Infrastructure Development in Rural Areas: New Initiatives, Yojana.Vol(... ), 18 (1999).

[8] Durai, B.K. et al., Planning of Rural Road in India- An overview of Selection, Criteria and Its Implications, IJRS. XXXII (2), 14-23 (2000).

[9] Ghosh B. and Dey D.P., How Different Categories of Infrastructure Affect Development-Evidence from Indian States, Economic and political weekly. 39 (2) (2004).

[10] Ansari S.H., Spatial Organization of Health Care facilities In Haryana, National Geographical Journal of India.51 (3-4), 51-62 (2005).

[11] Bhardwaj N.C et al., Rural Tele-Density, Economic and political weekly.41(5), 393-395 (2006).

[12] Bhatta B., Remote Sensing and GIS, Oxford University Press, 2 nd ed. (2011).

[13] Chaturvedi R., Spatial Data Infrastructure for District Level Planning Using Remote Sensing and GIs: A Case Study of Allahabad District, U.P., Ph.D., Banaras Hindu University, Varanasi. p.79 (2010).

[14] Pattanaik K., Sarva Sikhya Abhijan and Inclusive Education, Kurukshtra.58 (8), p.16-20 (2011).

[15] Official Records of the World Health Organization, No. 2, 100 (1946).

[16] Singh J.P., Transportation and Communication in Rural India: Some Facts, Kurukshtra. 49 (5), p.17 (2001).

[17] Myrdal G., Economic Theory and Underdeveloped Regions. London, Duckworth (1957).

[18] Sarkar S., Spatial Database for Rural Development and Planning Using Remote Sensing and GIS-A Case Study of Chandauli District,(U.P.), Ph.D. Thesis Banaras Hindu University. Varanasi. p.131 (2013).

\section{AUTHOR'S BIOGRAPHY}

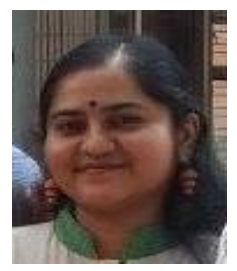

Dr. Sumana Sarkar, is an assistant professor of geography department in the University of Burdwan, West Bengal. Her primary research goal is directed towards uncovering the issues related to the application of geo-spatial techniques in regional planning. In addition to that she is also interested to explore the issues related to gender inequality, tribal and tourism development aspects. At present three JRF scholars are working under her supervision.

Citation: Dr. Sumana Sarkar. "Assessment of Level of Rural Infrastructure Development using Geospatial Techniques: A Case Study of Chandauli District (Uttar Pradesh), India”. International Journal of Research in Geography. vol 4, no. 2, 2018, pp. 34-46. doi:http://dx.doi.org/ 10.20431/2454-8685.0402004.

Copyright: (C) 2018 Authors. This is an open-access article distributed under the terms of the Creative Commons Attribution License, which permits unrestricted use, distribution, and reproduction in any medium, provided the original author and source are credited. 